Pobrane z czasopisma Annales N - Educatio Nova http://educatio.annales.umcs.pl Data: 26/04/2023 16:17:52

DOI: $10.17951 /$ en.2019.4.303-311

\begin{tabular}{lcr}
\hline & ANNALES \\
& UNIVERSITATIS MARIAE CURIE-SKŁODOWSKA & \\
LUBLIN - POLONIA & \\
VOL. IV & SECTIO N & 2019 \\
\hline
\end{tabular}

Jakub Wróblewski

Polskie Towarzystwo Ewaluacyjne

ORCID: https://orcid.org/0000-0001-5213-405X

jakub.j.wroblewski@gmail.com

\title{
Ewaluacja użyteczna. „Standardy ewaluacji” jako narzędzie wsparcia realizowanych badań
}

\author{
Practical Evaluation. "Evaluation Standards" \\ as a Project Supporting Tool
}

Streszczenie: Niniejszy artykuł przybliża czytelnikowi kluczowe zapisy „Standardów ewaluacji”, pozwalając jednocześnie poznać wyzwania, które są nieodłączną częścią pracy ewaluatorów. Pełna treść „Standardów ewaluacji” dostępna jest na stronie internetowej Polskiego Towarzystwa Ewaluacyjnego (www.pte.org.pl).

Słowa kluczowe: ewaluacja; standardy ewaluacji

\section{WPROWADZENIE}

„Standardy ewaluacji” zostały wypracowane w ramach projektu pn. „Wspólnie tworzymy standardy ewaluacji w Polsce”, zrealizowanego przez Polskie Towarzystwo Ewaluacyjne w 2008 roku. Dokument ten jest efektem wspólnej pracy środowisk zajmujących się ewaluacją: przedstawicieli administracji publicznej i organizacji pozarządowych, ewaluatorów, instytucji naukowych 
i niezależnych konsultantów. Standardy opracowano, aby wesprzeć osoby zaangażowane w proces ewaluacji oraz pomóc w zapewnieniu jak najwyższej jakości i użyteczności realizowanych badań. Są one zbiorem zasad i rekomendacji stojących na straży jakości badań, ale zabezpieczających także interes zlecających, ewaluatorów i osób uczestniczących w badaniach.

Dokument został podzielony na trzy główne części poświęcone kolejnym fazom realizacji badania ewaluacyjnego: od etapu planowania, przez realizację ewaluacji, aż po etap komunikowania wyników i wdrażania rekomendacji.

Niniejszy artykuł przybliża kluczowe zapisy „Standardów ewaluacji”, pozwalając jednocześnie poznać wyzwania, które są nieodłączną częścią pracy ewaluatorów. Pełna treść „Standardów ewaluacji” dostępna jest na stronie internetowej Polskiego Towarzystwa Ewaluacyjnego (www.pte.org.pl).

\section{KROK PIERWSZY: PLANOWANIE EWALUACJI}

Fundamentem wszelkich przedsięwzięć badawczych, zarówno komercyjnych, jak i tych o charakterze ściśle naukowym, jest określenie ich celów i zasadności. Standardy ewaluacji wskazują działania, które powinny mieć miejsce na tym kluczowym etapie.

Ocena zasadności podejmowania ewaluacji. Decyzja o realizacji konkretnego badania ewaluacyjnego powinna zostać podjęta w sposób odpowiedzialny, a w przypadku przedsięwzięć finansowanych ze środków publicznych z uwzględnieniem dobra publicznego. Należy dokonać analizy tego, czy realizacja badania, angażującego niekiedy znaczne siły osobowe i środki finansowe, jest zasadna z punktu widzenia potrzeb informacyjnych podmiotu zlecającego, ale też interesu publicznego. Kluczowa jest zatem odpowiedź na pytania, czy dana ewaluacja ma szansę przyczynić się do rozwoju oraz czy może być czynnikiem wpływającym na realną zmianę w procedurach, sposobie działania lub celach, jakie stawiają sobie dane podmioty.

Precyzyjne określenie celu, przedmiotu i zakresu badania. Jeśli realizacja ewaluacji jest uzasadniona, należy precyzyjnie określić jej cel, przedmiot i zakres w taki sposób, by był on czytelny i dla zlecającego, i dla ewaluatora. Należy również dokonać oceny tego, które podmioty (czy wręcz środowiska) powinny być włączone w proces ewaluacji - co ważne, nie tylko jako przedmiot analizy, lecz także w podmiotowej roli uczestników partycypacyjnego i otwartego procesu.

Wszystkie cele ewaluacji powinny być wyartykułowane w sposób niepozostawiający pola do interpretacji, który pozwoli na etapie zamykania projektu precyzyjnie określić stopień realizacji założonych celów projektu. 
Realistyczne określenie sposobu przeprowadzenia ewaluacji. Wyznaczenie celów ewaluacji i uczestników procesu badania jest punktem wyjścia do określenia metody przeprowadzenia badania i tym samym zasobów, które są niezbędne do jego realizacji. Wiedza o celach, metodzie i podmiotach, które zostaną włączone w ewaluację, umożliwia określenie zakresu danych, które będą pozyskiwane, oraz ich źródeł wraz ze wskazaniem, które dane zostaną dostarczone ewaluatorowi przez zamawiającego, a które powinien pozyskać samodzielnie w toku realizowanych prac. Ponadto należy określić, jakie kompetencje powinien posiadać zespół realizujący ewaluację, by móc w pełni wykorzystać potencjał danych i całościowego kontekstu realizacji badania (m.in. specyfiki zaangażowanych podmiotów, szerokiego kontekstu społecznego analizowanych procesów, potencjału interakcji społecznych między poszczególnymi aktorami).

Elementem planowania ewaluacji jest także analiza ryzyk, którymi jest obciążone każde przedsięwzięcie. Wystąpienie trudności i przeszkód w każdym projekcie badawczym jest zjawiskiem naturalnym, a prawdopodobieństwo ich wystąpienia rośnie wraz ze złożonością i czasem trwania projektu. Niekiedy sama metodologia i charakter projektu zwiększają prawdopodobieństwo wystąpienia ryzyk, związanych m.in. z konfliktowymi relacjami między poszczególnymi aktorami lub między wykonawcą ewaluacji a zlecającym. Ryzyka te należy zidentyfikować i przewidzieć środki, które będą im przeciwdziałać lub minimalizować skutki wystąpienia.

Trudności, a nawet sytuacje kryzysowe, nie muszą świadczyć negatywnie o profesjonalizmie badacza czy zamawiającego. To dopiero brak reakcji lub reakcje niewłaściwe obciążają ewaluatora, który powinien być na nie przygotowany.

Określenie przejrzystych kryteriów wyboru ewaluatora. Wybór wykonawcy ewaluacji powinien się odbywać z zachowaniem zasad konkurencji, a kryteria wyboru powinny być formułowane w sposób jasny i precyzyjny. W polskich realiach zdecydowana większość ewaluacji jest prowadzona na zlecenie instytucji administracji publicznej (choć należy podkreślić, że wciąż nie jest wykorzystywany pełny potencjał prorozwojowy, jaki ewaluacja może oferować organizacjom pozarządowym, szkolnictwu wyższemu, instytucjom biznesu). Oznacza to, że proces wyboru wykonawcy jest realizowany zgodnie z procedurami określonymi w ustawie Prawo zamówień publicznych. Ustawa nakłada na zlecających szereg obowiązków, które muszą być wypełnione w trakcie wyboru osoby lub podmiotu, któremu zostanie zlecona usługa. Mimo tych obostrzeń zlecający mają pewną autonomię w zakresie określenia sposobu oceny ofert oraz formułowania wymagań względem potencjalnych wykonawców, których dopuszcza się do udziału w postępowaniach przetargowych. Szczególnie ten drugi element wywołuje coraz szerszą dyskusję i zastrzeżenia części funkcjonujących 
na rynku ekspertów. Określenie wymagań względem wykonawców jest zrozumiałą praktyką, pozwalającą na wstępnym etapie postępowania wyselekcjonować te podmioty, które posiadają doświadczenie dające rękojmię wysokiej jakości. Nie budzi wątpliwości sam fakt, że zlecający wyznaczają minima (np. dotyczące liczby i charakteru zrealizowanych wcześniej przez oferentów zleceń czy też wartości projektów oddających skalę i złożoność zakończonych projektów), które muszą spełniać oferenci, aby ich oferty podlegały ocenie. Jednak przedmiotem debaty może być to, na ile poziom wymagań jest dostosowany do konkretnych zleceń i czy niekiedy nie jest on nieadekwatnie wysoki w stosunku do złożoności projektów będących przedmiotem przetargu. Ponadto nie można pomijać faktu, że często wymogi koncentrują się bardziej na samej wartości zrealizowanych zleceń, pomijając weryfikację ich merytorycznej wartości i zbieżności tematyki $\mathrm{z}$ tą właściwą dla badania, będącą przedmiotem postępowania.

Elementem dyskusyjnym jest także ograniczenie czasowe dotyczące posiadanego doświadczenia. Często stosowanym rozwiązaniem jest uznawanie doświadczenia zdobytego tylko w ciągu trzech lat poprzedzających postępowanie. W praktyce oznacza to, że szereg podmiotów lub niezależnych badaczy traci możliwość przedstawienia oferty, nawet jeśli dysponują szerokim i bogatym doświadczeniem, zdobytym np. w trakcie realizacji ewaluacji projektów z perspektywy 2007-2013. Rynek traci możliwość skorzystania z wiedzy i doświadczenia szeregu specjalistów jedynie dlatego, że ich doświadczenie w realizacji konkretnego profilu badań zostało zdobyte wcześniej niż przed trzema laty. Egzemplifikacją skrajną, ale dobrze ilustrującą istotę problemu, jest przykład ewaluatorek, które po urlopie macierzyńskim i wychowawczym powracają na rynek pracy. Ta grupa badaczek, niezależnie od ich faktycznej wiedzy i doświadczenia, jest wykluczona z możliwości ubiegania się o dużą część publicznych zleceń, ponieważ po powrocie na rynek pracy ich doświadczenie w świetle stosowanej praktyki jest bezwartościowe.

Zapewnienie niezależności ewaluacji i zgodności z zasadami etycznymi. Ewaluacja nie ma służyć samej ocenie, lecz ma przede wszystkim wspierać rozwój i naukę oraz pomagać w usprawnianiu pracy osób i instytucji. To kluczowe założenie nie zmienia faktu, że ewaluacja jest często traktowana jako bezpośrednia lub pośrednia ocena pracy konkretnych osób. Mimo że taka interpretacja zadań ewaluatora nie jest właściwa, to sprawia, że bardzo istotne jest zapewnienie mu niezależności. Autonomia badacza powinna być respektowana przez zlecającego, ale również sam ewaluator - świadomy odpowiedzialności, jaka na nim spoczywa - powinien stawiać na pierwszym miejscu etykę i niezależność swoich działań. To jego misją jest rzetelne zrealizowanie powierzonej mu pracy i w znacznej mierze od niego zależy, czy ulegnie ewentualnym formalnym 
lub nieformalnym naciskom ze strony decydentów. Ewaluator jest głównym obrońcą swojej niezależności, osobą wyznaczającą jej granice i stojącą na straży nie tylko etyki swoich działań, lecz także samego procesu ewaluacyjnego, stopnia jego uspołecznienia i publicznej kontroli.

\section{KROK DRUGI: REALIZACJA BADANIA}

Zrealizowanie powyższych założeń stanowi fundament rzetelnej ewaluacji. To jednak etap realizacji decyduje o tym, czy efekt finalny w postaci raportu będzie użytecznym narzędziem wspierającym decydentów, organizacje i wszystkich uczestników procesu. Opisując etap realizacji badania ewaluacyjnego, podano pięć wytycznych, które powinny być przestrzegane. Wskazano również zasady, który powinny znajdować się u podstaw budowania relacji między ewaluatorem a badanymi - relacji, które w odróżnieniu od innych rodzajów badań (np. w obszarze nauk psychologicznych czy medycznych) nie powinny charakteryzować się biegunową relacją między badaczem a badanym obiektem, lecz opierać się na partnerstwie i podejściu włączającym ewaluowanych w otwarty i demokratyczny proces.

Zapewnienie wysokiej jakości ewaluacji. Odpowiedzialność za zapewnienie wysokiej jakości ewaluacji leży zarówno po stronie ewaluatora, jak i zamawiającego. Ewaluator ma wiedzieć, do czego dąży, czemu służą kolejne podejmowane przez niego czynności i jaki ma być efekt tych prac. Specyfika badania ewaluacyjnego powoduje jednak, że zlecenie ewaluacji nie zdejmuje części odpowiedzialności za finalny efekt ze zleceniodawcy, m.in. w zakresie otwartej współpracy z uczestnikami procesu czy też samym ewaluatorem (np. w zakresie udostępniania mu niezbędnych danych i informacji). Tylko współpraca wszystkich środowisk i stron zaangażowanych $\mathrm{w}$ analizowane działania daje szansę na zrealizowanie ewaluacji zgodnie z ustalonym zakresem prac, harmonogramem i budżetem, o wysokiej wartości merytorycznej, mającej potencjał realnej zmiany.

Zapewnienie trafności i rzetelności badań ewaluacyjnych. Wskazana odpowiedzialność ewaluatora jest nierozerwalnie związana z wymogiem zapewnienia trafności i rzetelności badania. Realizacja ewaluacji opiera się na metodologii badań naukowych, która daje możliwość stosowania wielu podejść. Ich wybór powinien być dokonywany w relacji do celów i zakresu badania oraz dostępnych zasobów. By móc swobodnie dokonać wyboru podejścia metodologicznego oraz dopasować do niego odpowiednie metody i techniki badawcze, należy je znać i posiadać umiejętność ich stosowania. Zadaniem ewaluatora jest tak zaplanować badanie w oparciu o swoją wiedzę dotyczącą organizacji procesu ewaluacyjnego i posiadane zasoby, aby pozyskać trafne, rzetelne, adekwatne 
i wiarygodne dane, których analiza pozwoli odpowiedzieć na postawione pytania badawcze. Należy zwrócić uwagę na fakt, że odpowiedzialność ewaluatora obejmuje całość procesu badawczego, którego integralną częścią jest także sformułowanie kryteriów ewaluacji i dobór właściwych wskaźników. Badanie ewaluacyjne zatem nie powinno i nie może być postrzegane jako cykl niepowiązanych ze sobą czynności, lecz jako łańcuch spójnie powiązanych ze sobą i wynikających z siebie działań.

Dbanie o partycypacyjność i jakość współpracy w procesie ewaluacji. Aby wypełnić powyższe założenia, niezbędna jest partnerska i ścisła współpraca zamawiającego, uczestników procesu i ewaluatora. Te trzy strony powinny pozostawać $\mathrm{w}$ stałym kontakcie oraz w otwarty sposób informować się o przebiegu procesu ewaluacji i ewentualnych trudnościach.

Przestrzeganie warunków umowy. Umowa regulująca współpracę zlecającego i ewaluatora powinna w równym stopniu zabezpieczać interesy zlecającego, ewaluatora oraz uczestników ewaluowanego procesu, którzy nigdy nie mogą być sprowadzeni do milczącego przedmiotu badań. Zapisy powinny być formułowane w sposób jasny i precyzyjny.

Dbanie o jakość relacji ewaluator-badani. Oprócz zasad, które powinny określać normy współpracy ewaluatora z zamawiającym, niezbędne jest stosowanie szeregu reguł określających relacje pomiędzy ewaluatorem a osobami badanymi. Ewaluator jest zobowiązany do okazywania szacunku osobom zaangażowanym w badanie ewaluacyjne, co przejawia się m.in. w stosowaniu zasady poufności i anonimowości, a także zapewnieniu wszystkim badanym odpowiednich do ich potrzeb warunków do wypowiadania się oraz aktywnego uczestnictwa i posiadania wpływu na proces ewaluacji. Niezależnie od wyrażanych opinii ewaluator ma za zadanie zachować neutralność i obiektywizm wobec badanych. Powinien również dążyć do poznania kontekstu sytuacji badanych, cechować się wrażliwością i empatią do ich sytuacji, traktować ich nie jako przedmiot badania, tylko jako podmiot w procesie ewaluacyjnym.

\section{KROK TRZECI: ZWIEŃCZENIE PRAC}

Finalnym efektem pracy ewaluatora jest raport końcowy. To ten dokument jest materiałem, który podlega ocenie decydentów i opinii publicznej. Dlatego - niezależnie od metodologicznej finezji, profesjonalizmu działań i wnikliwości analizy - kluczowy dla odbioru ewaluacji jest etap komunikowania jej wyników. Autorzy „Standardów ewaluacji” sformułowali pięć wytycznych, które mają pomóc ewaluatorom i zleceniodawcom w pełni wykorzystać potencjał wiedzy, wniosków i rekomendacji opracowanych w toku całego procesu ewaluacyjnego, angażującego możliwie wiele zaangażowanych w niego środowisk. 
Zachowanie przejrzystości struktury i języka raportu ewaluacyjnego. Forma raportu i sposób prezentacji danych powinny być dopasowane do konkretnych potrzeb zlecającego, celu ewaluacji oraz grupy odbiorców. Język raportu powinien być jasny i zrozumiały dla czytelników o różnym poziomie kompetencji badawczych.

Zapewnienie rzetelności raportu ewaluacyjnego. Raport ewaluacyjny powinien zawierać rzetelną i możliwie pełną odpowiedź na zagadnienia zawarte w zamówieniu. W przypadku braku możliwości udzielenia konkluzywnych odpowiedzi na konkretne pytania taka informacja powinna być uwzględniona w raporcie wraz z wyjaśnieniem.

Tezy raportu powinny bazować wyłącznie na zebranym materiale empirycznym i analizie danych. Fakty powinny być w czytelny dla odbiorców sposób oddzielone od opinii ewaluatora lub ekspertów współuczestniczących w wybranych częściach badania.

Zamawiający nie powinien ingerować $\mathrm{w}$ wyniki badań ewaluacyjnych. Wprowadzanie zmian w raporcie może mieć miejsce wyłącznie za zgodą ewaluatora.

Formułowanie precyzyjnych wniosków i rekomendacji. Wnioski $\mathrm{w}$ raporcie powinny wynikać $\mathrm{z}$ zebranych $\mathrm{w}$ trakcie ewaluacji danych oraz rzetelnej i niezależnej analizy ewaluatora. Rekomenduje się, by w raporcie ewaluacyjnym wnioski i rekomendacje umieszczać w wydzielonym rozdziale. Powyższe wskazanie nie wyklucza możliwości równoczesnego umieszczenia ich w treści raportu jako logicznych wniosków wynikających z poszczególnych etapów prac badawczych. Oddzielny rozdział, zawierający tylko wnioski i rekomendacje, jest jednak znaczącym ułatwieniem dla czytelników, którzy chcą się skupić na tej części dokumentu.

Konsultowanie wniosków i rekomendacji. Kluczem do pełnego wykorzystania potencjału, jaki niesie za sobą ewaluacja, są właściwe wnioski, a także trafne i możliwe do wdrożenia rekomendacje. Po sformułowaniu wniosków powinna się odbyć poprowadzona w gronie interesariuszy dyskusja nad ich trafnością. Takie spotkanie może mieć formę panelu dyskusyjnego lub warsztatu, podczas którego uczestnicy powinni mieć prawo formułowania informacji zwrotnej dotyczącej wyników ewaluacji. Dyskusja powinna pozwolić również na doprecyzowanie rekomendacji oraz usunięcie lub skorygowanie tych ewidentnie nietrafnych i niemożliwych do wdrożenia.

W razie potrzeby powinien być opracowany protokół rozbieżności jako produkt procesu konsultacji.

Wykorzystanie rekomendacji. Wyniki ewaluacji powinny być wykorzystywane w procesach decyzyjnych, stanowić punkt wyjścia do zmian kultury 
organizacyjnej, rewizji metod i kierunków działania. W ramach procesu ewaluacji powinno się zadbać o opracowanie przejrzystych procedur wdrożenia rekomendacji, w tym określić cel i sposób ich wdrożenia wraz z podaniem, o ile to możliwe, adresatów rekomendacji oraz wstępnego harmonogramu.

\section{ZAKOŃCZENIE}

Dziś, po upływie ponad 10 lat, na nowo pochylamy się nad opracowanym zbiorem rekomendacji i wytycznych, które mają wspierać osoby zaangażowane w proces ewaluacji w zapewnieniu jak najwyższej jakości. Ostatnia dekada była czasem rozwoju i przemian zarówno samego sektora ewaluacyjnego, jak i całej branży badań społecznych. Rosnący poziom kompetencji zlecających i wykonawców, nowości metodologiczne i nowe obszary badawcze to pozytywne procesy, które wspierają rozwój tak ważnej dla nowoczesnego społeczeństwa branży ewaluacyjnej. Jednocześnie nie możemy być obojętni na negatywne zjawiska, na które zwracają uwagę sami badacze i odbiorcy ewaluacji. Uchybienia metodologiczne, powierzchowność wniosków, brak holistycznego i wnikliwego podejścia do analizowanych procesów, brak uspołecznienia, skupianie się na zbieraniu danych, a nie na pogłębionej analizie procesów, formułowanie niejasnych i nieprecyzyjnych rekomendacji - to tylko niektóre z podnoszonych przez zamawiających zarzutów. Choć odnoszą się one do przypadków skrajnych, to negatywnie wpływają na postrzeganie całej branży badawczej.

Szerokiej dyskusji wymaga także zakres stosowania wniosków płynących z tysięcy badań ewaluacyjnych realizowanych od poziomu JST do poziomu instytucji centralnych. Ewaluacja niepotrzebna, ewaluacja, której wnioski nie są poddawane ocenie decydentów, jest ewaluacją martwą, która nie ma szansy realizacji swojego fundamentalnego celu, jakim jest wspieranie procesu zarządzania projektami, instytucjami czy w końcu całym państwem.

Planowana rewizja "Standardów” jest okazją nie tylko do uwzględnienia w nich doświadczeń ostatnich lat i nowych wymagań rynku, lecz także szansą na dokonanie krytycznego namysłu nad kierunkiem rozwoju ewaluacji. Mamy sposobność podjęcia rozmowy o jej fundamentach i tym, na ile kierunek, w którym zmierza, jest spójny z założeniami i myślą, która znajduje się u jej źródeł. Ewaluacja w służbie biznesu, trzeciego sektora, administracji publicznej na poziomie centralnym i samorządowym może być niezwykle wartościowym narzędziem zmiany. Może być metodą opisu świata nie wyłącznie przez pryzmat miar i wskaźników, lecz także wartości. Jednak ewaluacja redukowana do roli jednego z wielu instrumentów zarządzania administracją jest narażona na ryzyko odejścia od swojej pierwotnej funkcji. 
Fenomen i wyjątkowość ewaluacji, która odróżnia ją od innych metod analizy procesów społecznych, zasadza się na jej demokratycznym i partycypacyjnym charakterze. Jest ona z założenia dynamicznym, interaktywnym procesem, angażującym różne grupy interesariuszy. W odróżnieniu od równie bardzo potrzebnego monitoringu czy audytu w ewaluację wpisane są dialog i responsywność. Zorganizowanemu w 2015 roku (był to Światowy Rok Ewaluacji) I Ogólnopolskiemu Kongresowi Ewaluacyjnemu przyświecało motto: „Integracja. Dialog. Rozwój”. Za każdym z tych trzech słów stoi szereg wartości oddających sens i istotę ewaluacji. Integracja różnych aktorów i środowisk, stworzenie im możliwości partycypacji w procesie ewaluacyjnym, tworzenie przestrzeni dialogu i wymiany opinii - to klucz do ewaluacji, jaką promuje Polskie Towarzystwo Ewaluacyjne. Ewaluacji, która - poza metodologicznym wyrafinowaniem, naukową rzetelnością i profesjonalizmem działania - powinna kierować się konstytuującymi ją wartościami, kierującymi ją w stronę demokratycznego i prorozwojowego procesu.

Identyfikacja i zrozumienie źródeł problemów stanowią podstawę wszystkich działań służących ich rozwiązywaniu. Głęboko wierzymy, że nowe „Standardy ewaluacji", uzupełnione o wnioski płynące z doświadczeń ostatnich lat, będą cennym głosem w publicznej debacie na temat ewaluacji i zarządzania opartego o dowody. Mamy też nadzieję, że wspólne tworzenie nowych standardów pozwoli na nowo ożywić ewaluację i przypomnieć o jej ważnej społecznej misji, która opiera się na założeniu, że proces ewaluacji generuje nie tylko potencjał wiedzy, lecz także wyzwala refleksję, nową jakość relacji, a więc może wpływać na zmianę zachowań i postaw.

Summary: The article introduces the reader to the key provisions of the "Evaluation Standards", while allowing to learn about the challenges that are an integral part of the evaluators' work. The full content of the "Evaluation Standards" is available on the website of the Polish Evaluation Society (www.pte.org.pl).

Keywords: evaluation; evaluation standards 